\title{
Computer Science Education in Malaysia Schools: The Challenges of Enhancing Computational Thinking Skills
}

\author{
Puganesri. K, Saifullizam Puteh
}

\begin{abstract}
The aim of this paper is to discuss the challenges of computational thinking in computer science subject at school in Ministry of Education Malaysia. The study focuses on teaching and learning of computational thinking skills and computer science at secondary school to cope with the expected situation towards Education 4.0. The contribution study addresses the problem of improving computational skills among students through computer science education. The survey was conducted using the interview method and involved 3 experienced teacher in computer science. Qualitative data were analyzed using thematic analyzed using thematic analysis to extract meaning to understand and explain the subject matter of the study. The findings show that there is a gap based on technology exposure between the generation of teachers and students, therefore computer science requires a module and teaching materials that feature the latest technology. The study also found that the existing curriculum was in line with the efforts of improving the student's computational thinking skills. Therefore, teacher training, modular facilities, and technological materials still need to be improved in parallel with the development of technological knowledge for the generation of students and towards education 4.0.
\end{abstract}

Index Terms: Computer Science Education; Computational Thinking Skill; Education 4.0; Teaching and Learning; Computer Science Curriculum.

\section{INTRODUCTION}

The Ministry of Education (MOE), has integrated the subject of computer science into the High School Curriculum (KPM, 2016). Computer Science subjects have a profound impact on social and economic life. Today, as we know that almost all generations, regardless of age and gender, are expected to have some tasks that require basic computer skills in parallel with emerging technology development (Sengupta, 2013; Durak \& Saritepeci, 2018). Computer science has an important position in other areas. How to make students more familiar with computer skills and knowledge, teach them how to use a computer that can make them easier to solve real problems in their daily lives.

Hence, computational thinking (CT) was introduced in schools to reinforce creative thinking and creative thinking skills among students. Computational Thinking (CT) is

Revised Manuscript Received on September 22, 2019

Puganesri.k, Faculty of Technical and Vocational Education, University Tun Hussein Onn Malaysia, Parit Raja, 86400 Batu Pahat, Johor, Malaysia

Saifullizam Puteh, Faculty of Technical and Vocational Education, University Tun Hussein Onn Malaysia, Parit Raja, 86400 Batu Pahat, Johor, Malaysia.saifull@uthm.edu.my. defined as the ability to adapt skills, knowledge, and values to make analysis and reflection to find solutions to problem-solving, innovation, imagination, and creative thinking in creating new ideas to solve problems in everyday human life. Computational thinking is one of the most important elements to build creativity, intelligence among human capital to meet the challenges of the 21 st century (Salleh and Puteh, 2017). Computational thinking is a kind of thinking skill that uses computer technology to process information. Therefore, the aim of the research is to identify the challenges faced by teachers and students on the application of computational thinking in computer science education.

This paper is organized as follows: in Section 2 of this paper a short summary of the related work regarding computer science education and computational thinking skills is presented. Details of our research methodology are presented in Section 3. Section 4 discussed the research findings and explanations for interpreting the interviews information of expert based on research objectives. Section 5 draws some conclusions and discusses the challenges of computational thinking skills and computer science at secondary school to cope with the expected situation towards Education 4.0.

\section{Literature REVIEW}

Teachers play an important role (Mohamad Zahid et al., 2017), in mastering and requiring in-depth knowledge of their computer science knowledge before applying and practicing them in the learning process at school. Therefore, the provision of school teachers in computer science using computational thinking skills before the learning process, especially the use of elements to solve problematic techniques in practical training is very important. (Zulkifli, 2016). This is because the application of computing thinking in the field of education is very important to improve students' thinking skills before they enter the field of work (Puteh et al., 2017; Sanusi and Puteh, 2017, Hassan and Puteh., 2017).

What is computational thinking? Computer science is the discipline which builds the solution by abstraction, transform it into programming and uses the computer to execute the instructions automatically (Barr, V., \& Stephenson, C. (2011). Computational thinking has the potential to improve thinking skills to solve problems, design systems, and train students to think critically and more creatively. There are

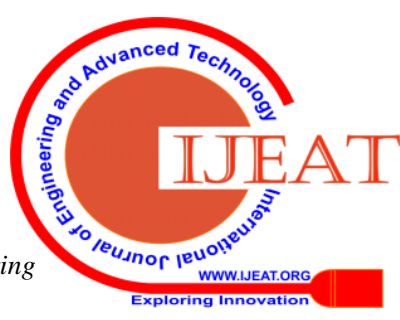


two parts in computation thinking, one is a computation, another is thinking. Computation is kind of thinking process which uses the computer to process the information while thinking is referred to human brain activities. In general, computational thinking is a combination between humans and machines that means human technology uses computers to solve problems (Ribeiro et al., 2013). Computation thinking skills can help human to solve the more complex problem into a simple and systematic way Fisk (2017). There are 4 basic elements in Computational Thinking is Decomposition, Abstraction, Pattern Recognition and Algorithm Logical (Barr Stephenson, 2011; Bernnan Resnick, 2012; Grover Pea, 2013).

Decomposition is related to abstraction. Students will understand the problem by analyzing it and evaluate the problem by dividing it into small components (Ying Li, 2016). Abstraction is the most important part of the computational thinking that students will look at certain parts of the problem which related to the situation and try to break ideas or information into small groups (Faber et al, 2017), Algorithms skills students needed to structure the solution to the problem or the way to getting to a solution identify important information and arrange logical steps in logical order while pattern recognition students recognizing patterns that allow for more accurate planning to avoid recurring (Leonard et al., 2017).

Besides that, Teacher is a good educator in the process delivery knowledge to students (Salleh and Puteh, 2017). Therefore, the role of the teacher in implementing CT skills in teaching and learning process is very important. Unfortunately, teachers' knowledge of CT still lows because they did not have proper guidelines to teach them. This also one of the main effect that students still weak in application computation thinking skills (Durak, et. al., 2018). According to Fisk (2017) found that most of the teacher use theoretical learning based on books in class and copied the contest and apply it to students without any redesigned according to the disciplinary content. Apart from teachers, students are also given emphasis on computational thinking skills because, as we know students also are still weak in solving their problems in the area of learning. Therefore, computational thinking skills should be applied to students to help them solve problems in critical and creative way (Gajewski, R.R. (2018). Critical thinking the ability to analyze information and solutions to problems is an essential skill in 21 st century education. According to (Darling-Hammond, L. 2010), Critical thinking can create new and innovative ideas that can solve problems and ability to effective decisions. Creative thinking student ability to think in innovation way. In creativity skills students can thinking in creatively way, working creatively with others and implementing innovation (Piirto, 2011; Hassan et al., 2018).

Computer science education can help students to provide and reinforce with computer skills, knowledge and values. Computer Science subjects are parallel to the goal of improving computational thinking to students to solve problems and help in making the best decisions in the right way and it also develops critical and creative thinking skills. Computer science also can produce students who can contribute to the development of digital technology as a new technology creator who can solve today and future problems as well as practice positive behaviors and pure values. In addition computer science education helps students to build knowledge about principles and concepts such as logic and algorithms, students can use programming as a method of solving problems, assessing and using existing systems and environments related to computing and provide ideas of improvements to development, generating creative and innovative ideas while developing applications and students can analyze problems using computational thinking skills with computer-assisted (KPM, 2016).

Other than that, the introduced of education 4.0 by MOE in our education system is also closely linked to computational thinking skills. In the education system 4.0 it involves advanced technology and challenges to various sectors. The purpose of introduced the 4.0 education system is to help and produce students, teachers, and employees who can solve the problem creatively and crisis. Education 4.0 can help students to train them to solved the problem and also motivate themselves in learning and teaching systems Henard, F., \& Mitterle, A (2010). Besides that, according to Fisk (2017), 4.0 education system, the role of a teacher is not only emphasized on the skills and knowledge but also the students need to know the resources of knowledge and skills to help solve the problem creatively and crisis.

\section{METHOdology}

The research used a qualitative approach. The method used to obtain the result for this research was conducting interviews at secondary schools which have a computer science subject syllabus. A Semi-structured interview was used in this research. According to Hamza Alshenqeeti (2014), the semi-structured interview is more flexible of a structured interview as "it allows depth to be achieved by providing the opportunity on the part of the interviewer to probe and expand the interviewer responses" according to (Rubin \& Rubin, 2005).

The interview is divided into two sources which are experienced teachers in computer science education (E1 and E2) and an officer from Department of Curriculum Development, District Education Offices. The interviews for this research involved three experts (E1, E2 and, E3) in computer science education fields at school which is construction science and technology. Interview is an important qualitative research method for helps the researchers explore and obtain in-depth information. According to Sulaiman et al. al, (2017) the interview information was transcribed, categorized and finally, themes were formed based on the categories.

According to Holstein \& Gubrium, (2011), data analysis is important to ensure that the data obtained can achieve the objective of the study. Data analysis for this study used theme generation techniques. As we know theme generation techniques are methods for identifying, analyzing and reporting the analysis contained. This technique can organize and analyze data in more detail than interpret various aspects of research achievement. All the information and data in this item have been reviewed and 
analyzed according to the need to appropriate the objectives and scope of the research study. The data were analyzed before the conclusion and suggestion were formed to ensure that the objectives of the research were achieved.

\section{RESUlT AND FINDINGS}

The findings of this research were analyzed and discussed based on the research objectives.

\section{A. Modules}

Computer science subject is more focused on practical lessons. "Even the teachers are well known experienced in computer skills but they still faced problem to deliver knowledge to the student because they did not have any special modules about computation thinking (E3)". "Teachers need some course on computer sciences subject because as we know majority teachers who teach CS their specific background graduate are not from computer science (E1)". "Computer science subject are more on thinking skills because students have to build programming by own self therefore students need guidelines related to computational thinking in computer science which means students need modules, notes for students to understand more deeply about the abstract thinking and logic thinking by thinking training and easier to apply the method of computational thinking to practice how to solve the problem (E2)".

Respondents knew the benefits of applying computational thinking skills in computer science to the students. According to Ying Li (2016), the main reason still does not have any proper computer knowledge so that teachers harder to explore the knowledge directly and easily. According to the wing (2006), computers do not think like humans to solve the problem but it will only execute the instructions received from humans. Teaching case based on computation thinking is used to students easier to distinguish the method of computer and human. These approaches are able to create an avenue for students to think and challenge themselves in a learning process and also will let know the student's relationship between computer and human (Sulaiman et. al., 2017).

Other than that, (Faber et. al., 2017) reported computer science is based on practical training, although students understand computer science by theoretical learning they still face a problem when students begin to apply them in a practical way using computers because students don't have right modules and rule from the educators. There are two differences between theoretical learning and practical learning. Theoretical learning is based on books while practical learning based on students thinking skills and create new ideas to solve the problem. This causes the student to not understand the real and basic principles of computer science and how to use the computer to solve the problem in their field through computational thinking skills (Kanev et al., 2017).

\section{B. Gap Based on Technology}

Most of the teachers had four major challenges about CT. First, they had a positive outlook about the execution of CT in the teaching and learning process because "as we all know nowadays the implementation of students is more influenced in technology. Today's students are more advanced than teachers, they can apply and create programming fast because of influenced by friends, internet and media (E1)". "Students can learn how to use thinking skill to solve the problem they face in regular daily (E2)" and "nowadays, life is full of challenges, where students need to train their thinking skills to creativity and critically and also learn how to generate ideas based on their knowledge (E3)".

However, they were worried about the ability of teachers in implementing on CT skills in computer science because "teachers did not have any training based on CT in computer science (E2)", "most of the teachers only have basic knowledge about CS and did not have any suitable training for teachers (E3)", and "Teachers did not have enough time and modules to learn CT because as we know CT skills is very important to form students with highly advanced in problem-solving skills (E1)".

Based on the aspiration of Malaysia Education Blueprint 2013-2025, teachers generally understand that CT needs to be infused through lesson for students' better achievement. These findings are in line with Sulaiman et al. (2017) who tried to infuse CT in academic and real-life purpose. However, according to (Rashid, 2016) to improve CT skills among teachers in teaching and learning. Teachers need to attend courses, seminar or programs related to the improvement of computation skills and receive updated information related to computational skills in computer science subject. Therefore, as (Fani,2010) express that computation thinking skills is not an easy task in applying computation thinking (CT) skills in the teaching process.

\section{LIMITATIONS AND SUgGESTIONS FOR FUTURE RESEARCH}

This study focuses on teaching and learning of computational thinking skills on computer science subject at secondary school to cope with the expected situation towards Education 4.0. Because, the usage of computational thinking skills in learning and teaching tool is still limited in our education system (Gajewski, R.R., 2018). Thus, I believe that researcher should be considered to help to obtain the information for more in-depth (Hazelkorn, E., \& Huisman, J., 2008) and recommended for students to develop and improving computational thinking skills in parallel with the development of technological knowledge for the generation of students and towards education 4.0. Other than that, future studies can perhaps improve the generation by using this computational skills at students with different ages and ability.

\section{Conclusions}

In the 2013-2025 Education Blueprint, the Ministry of Education (MOE), emphasizes computational thinking skills in computer science subjects to improve the quality of education systems in Malaysia (MOE, 2013). This aspiration is expressed as the seventh transition in education transformation program as expected by the MOE. The findings of this study are guidance in improving the computational thinking skills in computer science to teachers and students. Additionally, the findings of this study found that teachers and students still

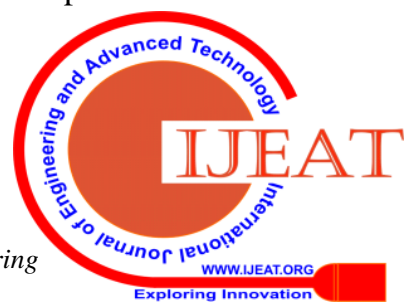


did not yet reached the level of computational thinking as required by the MOE, one of the reason was teachers and students still did not have a proper guideline in a computer science subject. Seconds, the teacher also suggests distributing modules and reference books related to computer science subject to help teachers to deliver teaching materials or products that can provide benefits to teaching and learning purposes in the future. Other than that, to improve CT skills, the teacher also need to attend various courses to implement CT skills in a computer science subject. In conclusion, CT skills now are needed in education 4.0, therefore to implement CT into computer science subject are the proper way to distribute higher qualification thinking skills among teachers and students.

\section{ACKNOWLEDGEMENTS}

The author would like to thank the Ministry of Higher Education, Faculty of Technical and Vocational Education, Research Management Centre Fund, Universiti Tun Hussein Onn Malaysia for supporting this research under the Grant VOT H041 and PPG V011.

\section{REFERENCES}

[1] Alshenqeeti H. Interviewing as a data collection method: A critical review. English Linguistics Research. 2014 Mar;3(1):39-45.

[2] Barr V, Stephenson C. Bringing computational thinking to K-12: what is Involved and what is the role of the computer science education community? Inroads. 2011 Mar 1;2(1):48-54.

[3] Darling-Hammond L. What we can learn from Finland's successful school reform. NEA Today Magazine. 2010;29(2).

[4] Durak HY, Saritepeci M. Analysis of the relation between computational thinking skills and various variables with the structural equation model. Computers \& Education. 2018 Jan 1;116:191-202.

[5] Faber HH, Wierdsma MD, Doornbos RP, van der Ven JS, de Vette K. Teaching computational thinking to primary school students via unplugged programming lessons. Journal of the European Teacher Education Network. 2017 Mar 31;12:13-24.

[6] Fani T. Overcoming barriers to teaching critical thinking. in the International Conference the Future of Education 2011 (pp. 1-5).

[7] Fisk P. Education $4.0 \ldots$ the future of learning will be dramatically different, in school and throughout life. URL: http://www.thegeniusworks.Com/2017/01/future-educationyoungeveryone-taught-together. 2017.

[8] Gajewski RR. ALGORITHMS, PROGRAMMING, FLOWCHARTS AND FLOWGORITHM. E-learning and Smart Learning Environment for the Preparation of New Generation Specialists.:393.

[9] Hassan NF, Puteh S. A survey of technology enabled active learning in teaching and learning practices to enhance the quality of engineering students. Advanced Science Letters. 2017 Feb 1;23(2):1104-8.

[10] Hassan NF, Puteh SB, Sanusi AB. Elements of Technology Enabled/Enhanced Active Learning (TEAL) to Enhance Quality and Employability of Bachelor's Students. InMATEC Web of Conferences 2018 (Vol. 150, p. 05005). EDP Sciences.

[11] Hazelkorn E, Huisman J. Higher education in the 21st century-diversity of missions. Higher Education Policy. 2008 Jun 1;21(2):147-50.

[12] Hénard F, Mitterle A. Governance and quality guidelines in Higher Education. A review of governance arrangements and quality assurance. Berlim: OECD. 2010.

[13] Holstein JA, Gubrium JF. The constructionist analytics of interpretive practice. The SAGE handbook of qualitative research. $2011 \mathrm{Apr}$ 27;4:341-58.

[14] Kanev D, Terziev V. Behavioral economics: development, condition and perspectives. IJASOS-International E-Journal of Advances in Social Sciences. 2017 Aug 31;3(8).

[15] Kementerian Pelajaran Malaysia. (2016). Program Pengkomputeraan, sains komputer dalam Kementerian Pendidikan Tinggi Malaysia. (2012). Ringkasan Eksekutif Pelan Pembangunan Pendidikan Malaysia 2013 - 2025 (Pendidikan Tinggi Kementerian Pendidikan
Malaysia. Dicapai pada Jun 2012 dari www.moe.gov.my. kurikulum 2017- Pendidikan

[16] Leonard J, Barnes-Johnson J, Mitchell M, Unertl A, Stubbe CR, Ingraham L. Developing Teachers' Computational Thinking Beliefs and Engineering Practices through Game Design and Robotics. North American Chapter of the International Group for the Psychology of Mathematics Education. 2017 Oct.

[17] Li Y. Teaching programming based on Computational Thinking. In2016 IEEE Frontiers in Education Conference (FIE) 2016 Oct 12 (pp. 1-7). IEEE.

[18] Ministry of Education (2013). Malaysian Education Blueprint 2013-2015 (Preschool to Post-Secondary Education), Putrajaya Malaysia.

[19] Puteh S, Maisarah M, Rosnawati B. Employability Skills Mastery of Special Needs Students at Polytechnics. VOL. 25 (S) May 2017. 2017 May 1:41.

[20] Rashid ZA. Tahap Kesediaan Guru Dalam Aspek Pengetahuan Dan Keperluan Latihan Berfokuskan Aplikasi KBAT (Doctoral dissertation, Universiti Tun Hussein Onn Malaysia).

[21] Rubin HJ, Rubin IS. Structuring the interview. Qualitative interviewing: The art of hearing data. 2005; 2:129-51.

[22] Ribeiro L, Nunes DJ, da Cruz MK, de Souza Matos E. Computational thinking: Possibilities and challenges. In2013 2nd Workshop-School on Theoretical Computer Science 2013 Oct 15 (pp. 22-25). IEEE.

[23] Salleh NN, Puteh S. A Review of the 21st Century Skills in Technical Vocational Education and Training (TVET). Advanced Science Letters. 2017 Feb 1;23(2):1225-8.

[24] Sanusi AM, Puteh S. An Approach of Excellence Talent in Engineering Education Programme of Enhancing the Quality of Students. Advanced Science Letters. 2017 Feb 1;23(2):1109-12.

[25] Sulaiman T, Muniyan V, Madhvan D, Hasan R, Syrene S, Rahim A. Implementation of higher order thinking skills in teaching of science: A case study in Malaysia. International Research Journal of Education and Sciences (IRJES). 2017;1(1):2550-158.

[26] Sengupta P, Kinnebrew JS, Basu S, Biswas G, Clark D. Integrating computational thinking with K-12 science education using agent-based computation: A theoretical framework. Education and Information Technologies. 2013 Jun 1;18(2):351-80.

[27] Wing JM. Computational thinking. Communications of the ACM. 2006 Mar 1;49(3):33-5.

[28] Zahid M, Che NH, Hanafi NM, Puteh S. Instructional Rubrics as an Alternative Approach for Improving Practical Teaching Among Teachers Candidate. Advanced Science Letters. 2017 Feb 1;23(2):1229-33.

[29] Zulkifli, Z. Keberkesanan Kaedah Pembelajaran Berasaskan Masalah dalam Meningkatkan Kemahiran Pemikiran Komputasional dan Menyelesaiakn Masalah dalam Kalangan Pelajar, Tesis Sarjana, Universiti Tun Hussein Onn Malaysia,2016

\section{AUTHORS PROFILE}

\section{Puganesri.k,}

I am Puganesri.k,currently I am affiliated with Faculty of Technical and Vocational Education, University Tun Hussein Onn Malaysia, Parit Raja, 86400 Batu Pahat, Johor, Malaysia

\section{Saifullizam Puteh}

I am Saifullizam Puteh, currently I am affiliated with Faculty of Technical and Vocational Education, University Tun Hussein Onn Malaysia, Parit Raja, 86400 Batu Pahat, Johor, Malaysia. saifull@uthm.edu.my. 